\title{
Scaling of Biodegradable Polyhydroxyalkanoates Synthesis Technology in Pilot Production Conditions
}

\author{
Evgeniy G. Kiseleva,b*, Aleksey V. Demidenko ${ }^{\mathrm{a}, \mathrm{b}}$, \\ Sergey V. Baranovskiy ${ }^{a, b}$ and Tatiana G. Volova ${ }^{a, b}$ \\ ${ }^{a}$ Siberian Federal University, \\ 79 Svobodny, Krasnoyarsk, 660041, Russia \\ ${ }^{b}$ Institute of Biophysics SB RAS, \\ 50/50 Akademgorodok, Krasnoyarsk, 660036, Russia
}

Received 07.08.2014, received in revised form 18.08.2014, accepted 21.08.2014

On the basis of experimentally achieved and developed technical and technological parameters of biosynthesis processes the baseline data were obtained and the project was worked out for organization of pilot production of degradable polyhydroxyalkanoates (PHAs). The pilot line for production of polyhydroxyalkanoates was designed, equipped and commissioned, including the "Bioengineering" fermentation line (Switzerland), as well as the blocks for preparation of inoculum and culture media, isolation and purification of polymers. The pilot production was commissioned. When the initial concentration of inoculum was $(10 \pm 2) \mathrm{g} / \mathrm{l}$ and the cultivation duration was $65 \mathrm{~h}$, the final concentrations of cells biomass in the culture of Cupriavidus eutrophus B10646 and polymer were (110 \pm 10$) \mathrm{g} / \mathrm{l}$ and $(85 \pm 5) \%$, with the process productivity by biomass and PHA of 1.7 and $1.4 \mathrm{~g} / \mathrm{l} \cdot \mathrm{h}$, respectively, which is twice as high as the previously achieved results in the culture of Ralstonia eutrophus B5786 on fructose. Scaling the technology made it possible to obtain the experimental batches of polymers in the amounts needed for conducting a complex of prescribed research, development and standardization of specialized polymer products.

Keywords: pilot production, baseline data, designing, procurement, equipment, material costs, process indicators.

(C) Siberian Federal University. All rights reserved

* Corresponding author E-mail address: evgeniygek@gmail.com 


\title{
Масштабирование технологии синтеза
}

\section{биодеградируемых полигидроксиалканоатов \\ в условиях опытного производства}

\author{
Е.Г. Киселев ${ }^{\mathrm{a}, \tilde{\sigma}}$, А.В. Демиденко $0^{\mathrm{a}, \boldsymbol{\sigma}}$, \\ С.В. Барановский ${ }^{\mathrm{a}, \mathbf{6}}$, Т.Г. Волова ${ }^{\mathrm{a}, \boldsymbol{0}}$ \\ ${ }^{a}$ Сибирский федеральный университет \\ Россия, 660041, Красноярск, пр. Свободный, 79 \\ ${ }^{6}$ Институт биофизики СО РАН \\ Россия, 660036, Красноярск, Академгородок, 50/50
}

На основе экспериментально достигнутых технико-технологических показателей процессов биосинтеза получены исходные данные и разработан проект создания опытного производства разрушаемых полигидрокисалканоатов (ПГА). Сконструировано, укомплектовано и введено в строй пилотное производство полигидроксиалканоатов, включающее ферментационную линию «Bioengineеring» (Швейцария) и блоки получения инокулята и питательных сред, выделения и очистки полимеров. Опытное производство введено в строй. При исходной концентрации

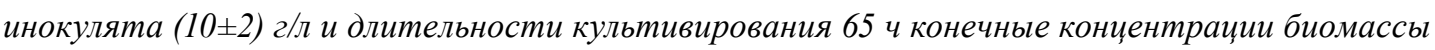

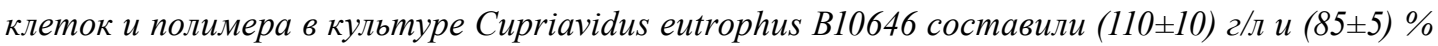
при продуктивности процесса по биомассе и ПГА 1,7 u 1,4 г/л·ч соответственно, что вдвое превосходит ранее достигнутые показатели в культуре Ralstonia eutrophus B5786 на фруктозе. Маситабирование технологии обеспечило получение опытных партий полимеров в количествах, необходимых для проведения комплекса регламентированных исследований, разработки и стандартизации специиализированной полимерной продукции.

Ключевые слова: опытное производство, исходные данные, проектирование, комплектация, оборудование, материальные затраты, показатели процесса.

\section{Введение}

Реализация любой новой микробной технологии в условиях опытного производства (ОП) является необходимым этапом для масштабирования процесса и последующей реализации промышленного производства. Испытание технологии в условиях ОП позволяет уточнить физико-химические параметры процесса ферментации, составить материальноэнергетический баланс, разработать технологический регламент и получить партии продукта, необходимые для проведения комплекса необходимых испытаний.
Первое отечественное ОП полигидроксиалканоатов (ПГА) было сконструировано и введено в строй в январе 2005 г. на базе Красноярского научного центра Сибирского отделения РАН в ходе сотрудничества Института биофизики СО РАН и отдела биотехнологии OAO «Биохиммаш» (г. Москва) в рамках проекта Международного научно-технического центра (МНТЦ-ISTC) (Волова и др., 2006). Создание производства полигидроксиалканоатов стало логическим результирующим этапом комплексных многопрофильных научных исследований, выполненных в Инсти- 
туте биофизики СО РАН в конце 90-х - начале 2000 гг. Производство было укомплектовано серийным оборудованием отечественного производства и нестандартным оборудованием, изготовленным в Институте биофизики СО РАН, включая оборудование для получения инокулята, производственный ферментер и блок экстракции полимеров. В основу процесса была положена технология с использованием штамма бактерий Ralstonia eutrophus В5786 на фруктозе с выходами по биомассе и полимеру до 50 г/л и 80-85 \% соответственно. Достигнутые показатели продуктивности по общей биомассе и полимеру составили 0,045 и 0,036 кг/ч.

Исследования, выполненные в последующие годы, в том числе в рамках мегапроекта «Биотехнологиии новых биоматериалов», реализуемого под руководством ведущего ученого профессора MIT (США) Энтони Джона Сински (Постановление Правительтства РФ № 220 от 9 апреля 2010 г.), в результате которых удалось значительно увеличить продуктивность процесса биосинтеза ПГА за счет полученного штамма бактерий Cupriavidus eutrophus В-10646, обладающего способностью синтезировать ПГА различной химической структуры на различных углеродных источниках, позволили приступить к разработке проекта нового и более продуктивного опытного производства (ОП).

\section{Исходные данные \\ для проектирования \\ опытного производства \\ разрушаемых \\ полигидроксиалканоатов (ПГА)}

На основании анализа полученных результатов синтеза полимеров в различных режимах (автотрофном и гетеротрофном) для масштабирования выбран вариант процесса, реализуемый на глюкозе. В результате проведённых работ удалось значительно увеличить выход ПГА с 2 кг за цикл до 9,5 кг. В качестве углеродного субстрата используется более дешевая глюкоза (Volova et al., 2013; 2014). Bpeмя экстракции сокращено с 12 до 8 ч. Вместо длительного процесса отстаивания используется фильтрация, в результате чего время отделения шрота от экстракта сократилось до 8 ч. Предварительная обработка биомассы раствором детергента позволила увеличить степень извлечения ПГА до 98,5 \%, а также избежать образования азеотропных смесей, в результате чего возможна регенерация и возврат в процесс растворителей.

В основе проекта - экспериментально достигнутые показатели процесса синтеза ПГА культурой C. eutrophus В10646. Исходные данные для разработки проекта приведены в табл. 1. Полученные исходные данные легли в основу проекта опытного производства ПГА и выбора производственного оборудования.

Таблица 1. Исходные данные, использованные для проектирования опытного производства

\begin{tabular}{|c|c|c|}
\hline Наименование & Значение & Примечание \\
\hline 1 & 2 & 3 \\
\hline Производственный штамм & $\begin{array}{c}\text { Cupriavidus eutrophus } \\
\text { B-10646 }\end{array}$ & \\
\hline Основной ростовой субстрат & $\begin{array}{c}\text { Глюкоза } \\
\text { ГОСТ } 975-88\end{array}$ & Гетеротрофный режим \\
\hline Режим процесса выращивания бактерий & периодический & \\
\hline $\begin{array}{l}\text { Длительность цикла с учетом получения посевного } \\
\text { материала, ч }\end{array}$ & $60 \pm 5$ & \\
\hline
\end{tabular}


Продолжение табл. 1

\begin{tabular}{|c|c|c|}
\hline 1 & 2 & 3 \\
\hline Концентрация клеток в посевном материале, г/л & $10 \pm 2$ & \\
\hline Конечная концентрация биомассы клеток в культуре, X, г/л & $110 \pm 10$ & \\
\hline Концентрация ПГА в посевном материале, \% & не выше 10 & \\
\hline Длительность получения посевного материала, ч & $5 \pm 1$ & Хемостат \\
\hline Длительность первого этапа периодического процесса, ч & $27 \pm 3$ & $\begin{array}{c}\text { Лимит азота, } 50 \% \text { от } \\
\text { потребности }\end{array}$ \\
\hline Длительность второго этапа периодического процесса, ч & $27 \pm 3$ & Азот отсутствует \\
\hline Конечная концентрация ПГА в клеточной биомассе, \% (к асб.) & $\begin{array}{l}\text { не ниже } \\
85 \pm 5\end{array}$ & \\
\hline Продуктивность процесса по биомассе, X, г/л ч & $2,0 \pm 0,1$ & \\
\hline Продуктивность процесса по продукту (ПГА), г/л•ч & $1,7 \pm 0,1$ & \\
\hline Удельный расход кислорода, г/г ПГА & $0,045 \pm 0,001$ & \\
\hline $\begin{array}{l}\text { Диапазон концентрации растворенного кислорода } \\
\text { в культуре, г/л }\end{array}$ & $2-5$ & \\
\hline Удельный расход глюкозы, г/г ПГА & $2,9 \pm 0,1$ & \\
\hline Текущая концентрация глюкозы в культуре, г/л & $5-35$ & $\begin{array}{c}\text { Ниже } 5 \text { - лимит, выше } \\
35 \text { - ингибирование } \\
\text { культуры }\end{array}$ \\
\hline $\begin{array}{l}\text { Пределы поддержания концентрации кислорода в культуре, } \\
\text { г/л: } \\
\text {-первый этап процесса } \\
\text {-второй этап }\end{array}$ & $\begin{array}{c}2-5 \\
5 \pm 0,5\end{array}$ & $\begin{array}{c}\text { Зависимость } \\
\text { культуры } \mu / \mathrm{So}_{2} \text { резко } \\
\text { экстремальная }\end{array}$ \\
\hline $\begin{array}{l}\text { Удельная подача азота в форме } \mathrm{CO}\left(\mathrm{NH}_{2}\right)_{2} \text { в культуру, мг/г: } \\
\text {-первый этап процесса } \\
\text {-второй этап }\end{array}$ & $\begin{array}{c}60 \\
0\end{array}$ & $\begin{array}{l}\text { Первый этап - } 50 \% \\
\text { от физиологической } \\
\text { потребности }\end{array}$ \\
\hline Текущая остаточная концентрация азота в культуре, мг/л & $50-100$ & $\begin{array}{c}\text { Первая стадия } \\
\text { периодического } \\
\text { процесса }\end{array}$ \\
\hline $\begin{array}{l}\text { Источник минеральных макро- и микроэлементов (г/л): } \\
\mathrm{Na}_{2} \mathrm{HPO}_{4} \cdot \mathrm{H}_{2} \mathrm{O}-9,1 ; \mathrm{KH}_{2} \mathrm{PO}_{4}-1,5 ; \mathrm{MgSO}_{4} \cdot \mathrm{H}_{2} \mathrm{O}-0,2 ; \\
\mathrm{Fe}_{3} \mathrm{C}_{6} \mathrm{H}_{5} \mathrm{O}_{7} \cdot 7 \mathrm{H}_{2} \mathrm{O}-0,025\end{array}$ & $\begin{array}{c}\text { стандартная среда } \\
\text { Шлегеля. } \\
\text { Железо лимоннокислое } \\
\text { Микроэлементы - } \\
\text { по Хоагланду }\end{array}$ & $\begin{array}{l}\text { При увеличении X, } \\
\text { Г/л, свыше } 10, \text { вносить } \\
\text { концентрат среды в } \\
\text { режиме подпитки }\end{array}$ \\
\hline $\begin{array}{l}\text { Температура культуры, }{ }^{\circ} \mathrm{C} \\
\text { рH }\end{array}$ & $\begin{array}{c}31 \pm 1 \\
6,8 \pm 0,2\end{array}$ & Автоматическое \\
\hline $\begin{array}{l}\text { Концентрирование биомассы: } \\
\text { выпаривание при абсолютном давлении, МПа; } \\
\text { центрифугирование при } n \text {, об/мин } \\
\text { Концентрация биомассы после упаривания, г/л }\end{array}$ & $\begin{array}{l}0,008-0,01 \\
5000-6000 \\
350\end{array}$ & $\begin{array}{l}\text { Вакуум-выпарная } \\
\text { установка, } 15 \text { мин }\end{array}$ \\
\hline Экстракция ПГА комбинированным способом в течение, ч & 8 & $\begin{array}{c}\text { Турбинная мешалка, } \\
\text { объем аппарата } 0,02 \mathrm{~m}^{3}, \\
n=900 \text { об/мин }\end{array}$ \\
\hline Фильтрация экстракта от шрота, ч & 4 & $\begin{array}{c}\text { Тканевый нутч-фильтр с } \\
\text { мешалкой }\end{array}$ \\
\hline Выделение полимера из экстракта осаждением в гексане, ч & 0,2 & $\begin{array}{c}\text { Осадительная ванна } \\
\text { с перемешиванием, } \\
\text { вытяжной шкаф }\end{array}$ \\
\hline Сушка полимера, ч. при $40-60{ }^{\circ} \mathrm{C}$ & 10 & Сушильный шкаф \\
\hline Регенерация растворителей & разгонка & $\begin{array}{c}\text { Разгонка: кубовая } \\
\text { емкость дефлегматор, } \\
\text { приёмная ёмкость }\end{array}$ \\
\hline
\end{tabular}




\section{Технология производства полигидроксиалканоатов}

Опытное производство размещено в отдельно стоящем на территории Сибирского федерального университета 2-этажном здании общей площадью $800 \mathrm{~m}^{2}$. Собственно опытное производство полимеров (ферментационное отделение) размещено на первом этаже

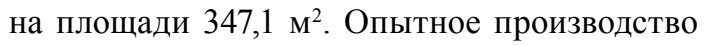
включает серию специализированных помещений: отделение чистой (музейной) культуры, отделение приготовления питательных сред и автоклавирования, ферментационный зал, блок для дежурных операторов, вспомогательные и хозяйственные помещения.

Общая схема ОП содержит следующие стадии технологического процесса: приготовление питательной среды; получение инокулята; ферментацию; концентрирование бактериальной суспензии; выделение, очистку и сушку продукта (полимера).

Отделение средоподготовки. В отделении реализуются следующие стадии технологического цикла:

- стадия приготовления маточных растворов;

- стадия стерилизации.

Блок-схема отделения средоподготовки представлена на рис. 1.

В отделении имеются весы для взятия навески солей, дистиллятор для получения воды, автоклавы, предназначенные для стерилизации посуды и маточных растворов. Вся посуда (колбы, пробирки) предварительно должна быть простерилизована в автоклаве насыщенным водяным паром при давлении 0,1013 МПа. Для приготовления маточных растворов берут соответствующие навески сухих солей и растворяют дистиллированной водой при комнатной температуре. Для получения воды для приготовления питательных сред и получения инокулята используют ак- вадистиллятор электрический производительностью 25 л/ч.

Отделение музейной культуры. Отделение предназначено для хранения и поддержания музейной культуры, а также для первой фазы получения инокулята. Стадия инокуляции включает получение суспензионной жидкой культуры из музейной культуры. Для этого с использованием шейкера-инкубатора и стеклянных колб на первой фазе получения инокулята получают объем культуры для засева посевного 30-литрового ферментера. После доведения рабочего объема до 20 л включают проточный режим для наработки посевной культуры для стадии ферментации. Блок-схема производства инокулята представлена на рис. 2.

Ферментаиионная линия. В ферментационном зале установлены: ферментёринокулятор, производственный ферментёр, парогенератор, вакуум-выпарная установка, сборник упаренной культуральной жидкости. В данном отделении реализуют следующие стадии технологического процесса: процесс масштабированного получения инокулята в ферментёре-инокуляторе (вторая фаза получения инокулята); ферментация; концентрирование бактериальной культуры (суспензии) и получение биомассы в виде пасты. Блоксхема отделения ферментации приведена на рис. 3.

Постферментаиионная стадия. После окончания стадии ферментации культуральная жидкость в количестве 100-110 л, содержащая не менее 100 г/л биомассы, сливается в сборник культуральной жидкости и далее подаётся на упаривание в вакуум-выпарную установку. Вакуум-выпарная установка предназначена для сгущения бактериальной суспензии путем испарения воды (10-50 кг/ч) при ее кипении под вакуумом (рабочее абсолютное давление 0,013-0,02 МПа). Установка 


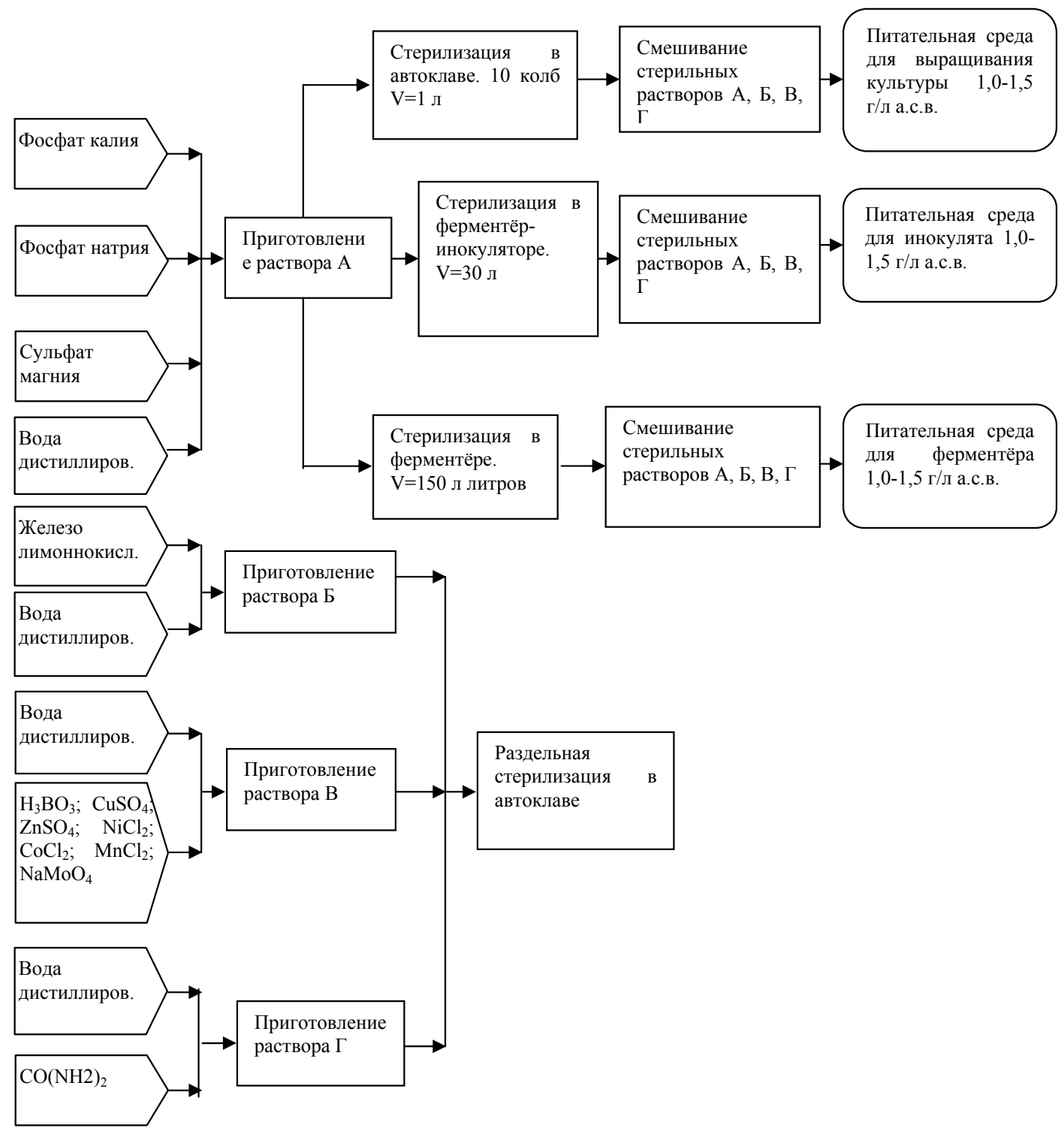

Рис. 1. Блок-схема технологических операций отделения средоподготовки

обвязана трубопроводом для подвода холодной воды в конденсатор и вакуум-насос, а также снабжена паропроводом для подвода пара в греющую камеру и гибким шлангом для отвода конденсата. В вакуум-выпарном аппарате происходит упаривание культуральной жидкости от 100 г/л в полученной культуре до концентрации 300-350 кг/м². Далее упаренная культуральная жидкость подаётся в сборник упаренной суспензии, установлен- ный в блоке экстракции и очистки полимера, объёмом 50 л.

Все стадии процесса ферментации ведутся в герметичном оборудовании, которое исключает возможность контакта культуральной жидкости с окружающей средой.

Получение готового продукта. Данное отделение предназначено для выделения и очистки продукта (полимера). Функцией данного отделения предусмотрены следующие 


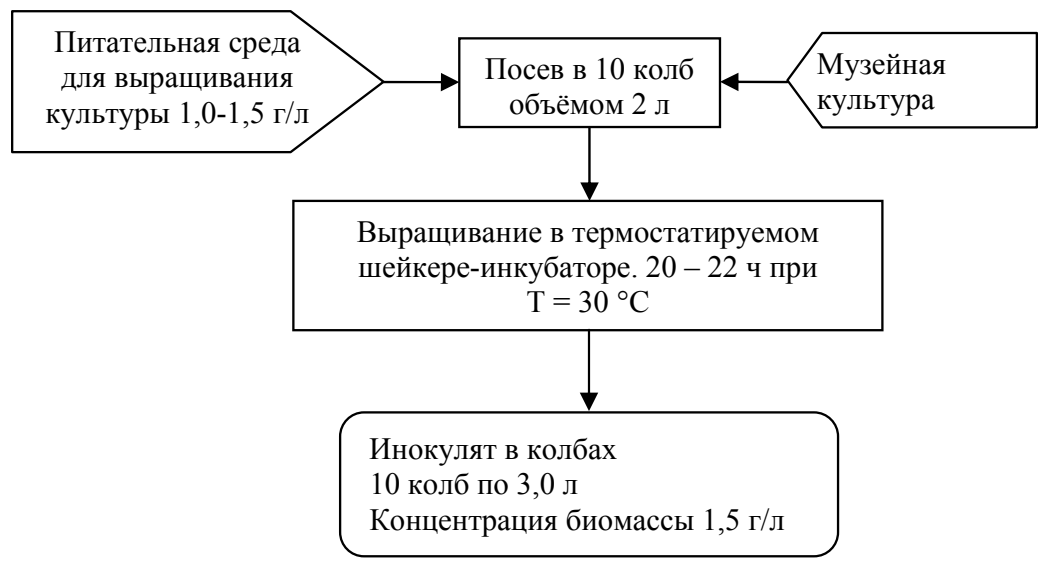

Рис. 2. Блок-схема отделения музейной культуры и подготовки инокулята

стадии технологического цикла: выделение и очистка полимера; сушка полимера. Блоксхема экстракции и очистки полимера представлена на рис. 4.

Упаренная культуральная жидкость в количестве 35 л центрифугируется. После отбора сгущенной биомассы в виде пасты супернатант (надосадочная жидкость) после инактивации острым паром сливается в сборник, а полученная паста с влажностью 50-60 \% в количестве 18-20 кг поступает на экстракцию.

Для экстракции полимера из полученной сырой пасты готовится 5\%-ный раствор ДДС$\mathrm{Na}$ объемом 50 л. Затем паста загружается в реактор и заливается раствором ДДС-Nа в соотношении 4-5 л/кг биомассы. Реактор снабжен мешалкой и терморубашкой для поддержания температуры.

Процесс экстракции длится 60 мин при температуре $(60 \pm 5){ }^{0} \mathrm{C}$ и активном перемешивании. Затем полученный экстракт центрифугируется, фугат инактивируется и сливается в сборник для последующей утилизации, а полученный полимер с примесью ДДС-Na подвергается промывке дистиллированной водой. Далее полимер отделяется от промывной воды центрифугированием и дополнительно трёхкратно промывается дистиллированной водой. Очищенный и промытый полимер в количестве $(9 \pm 1)$ кг сушат при температуре $60{ }^{\circ} \mathrm{C}$ в течение 24 ч. Конечный продукт (в случае необходимости) стерилизуют и асептически упаковывают.

Все технологические стадии в данном отделении связаны с контактом готового продукта с окружающей средой. Для исключения загрязнения продукта и обеспечения высокого качества все процессы ведутся в соответствии со стандартом GMP (Good Manufacturing Practice for medicinal products, ГОСТ Р 52249-2009). Данное отделение относится к классу D. Для обеспечения стерильности отделение оснащено санитарным тамбуром и передаточным окном со встроенными УФ-облучателями, изолированной системой приточно-вытяжной вентиляции, которая обеспечивает ламинарный поток воздуха от потолка к полу.

\section{Технологическая схема опытного производства}

Комплектация опытного производства выполнена в соответствии с технологической схемой процесса и включает поблочно уком- 


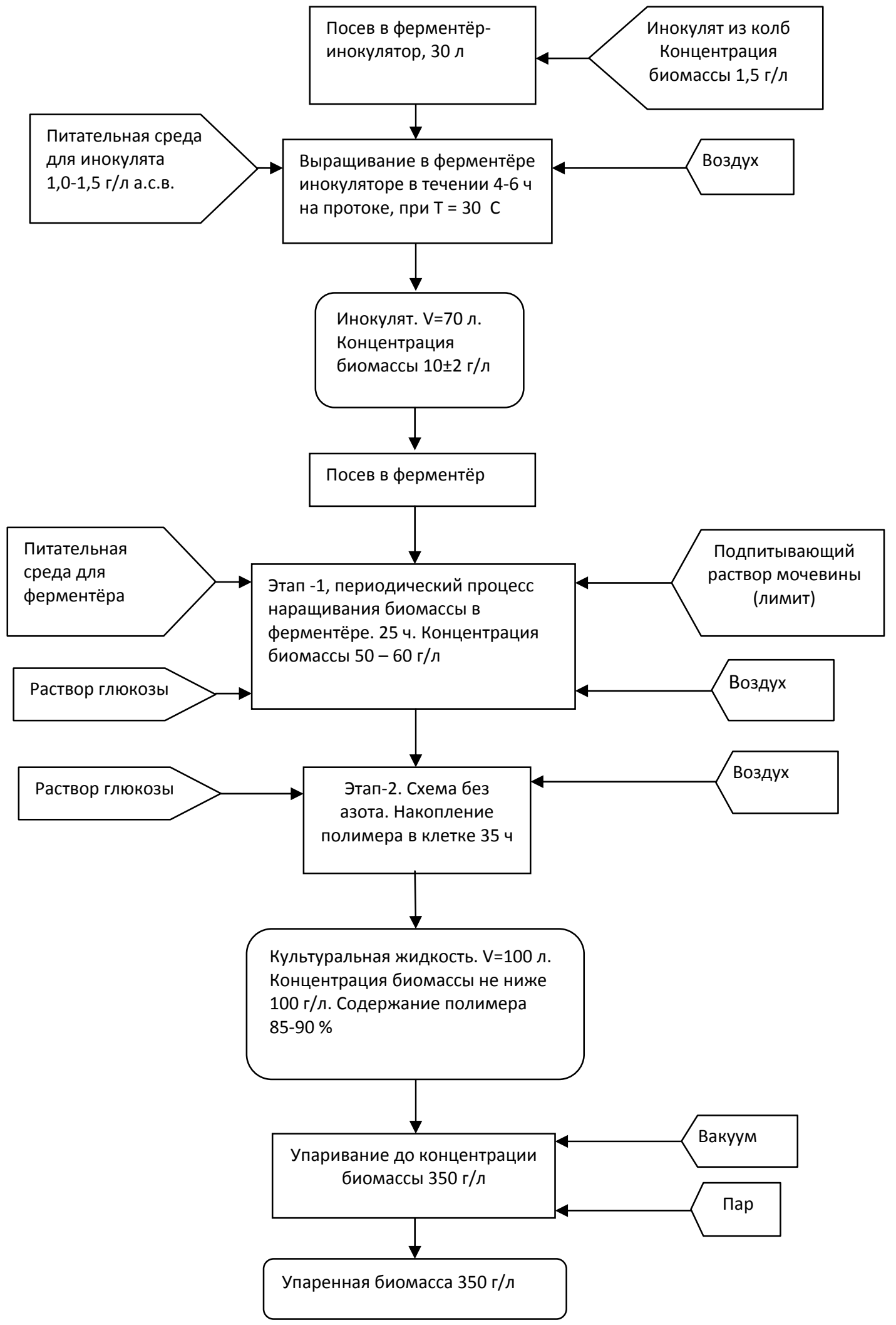

Рис. 3. Блок-схема стадии ферментации 


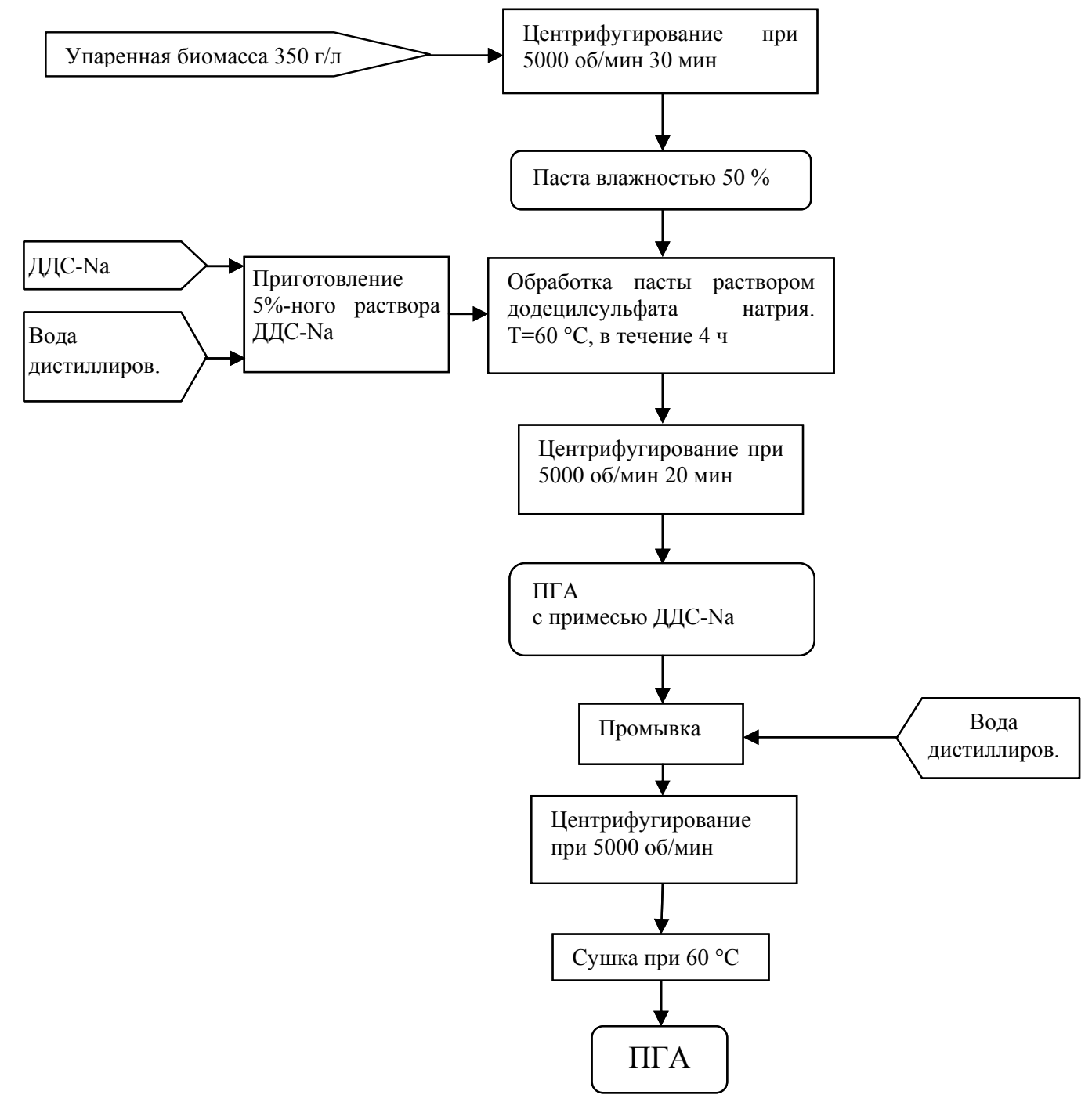

Рис. 4. Блок-схема блока экстракции и очистки полимера

плектованные участки. Общий вид ферментационной линии ОП показан на рис. 5.

Интегрирование блок-схем отдельных этапов технологического процесса позволило разработать общую технологическую схему процесса получения ПГА в условиях опытного производства (рис. 6). В табл. 2 представлен перечень оборудования, использованного для комплектации ОП.

Технологический цикл процесса синтеза полимеров (ПГА) состоит из следующих операций и стадий:
- стадия приготовления растворов;

- стерилизация полученных растворов;

- подготовка питательных сред;

- получение инокулята из музейной культуры в колбах;

- масштабирование получения инокулята в ферментёре-инокуляторе;

- двустадийная ферментация в производственном ферментёре;

- концентрирование бактериальной культуры; 


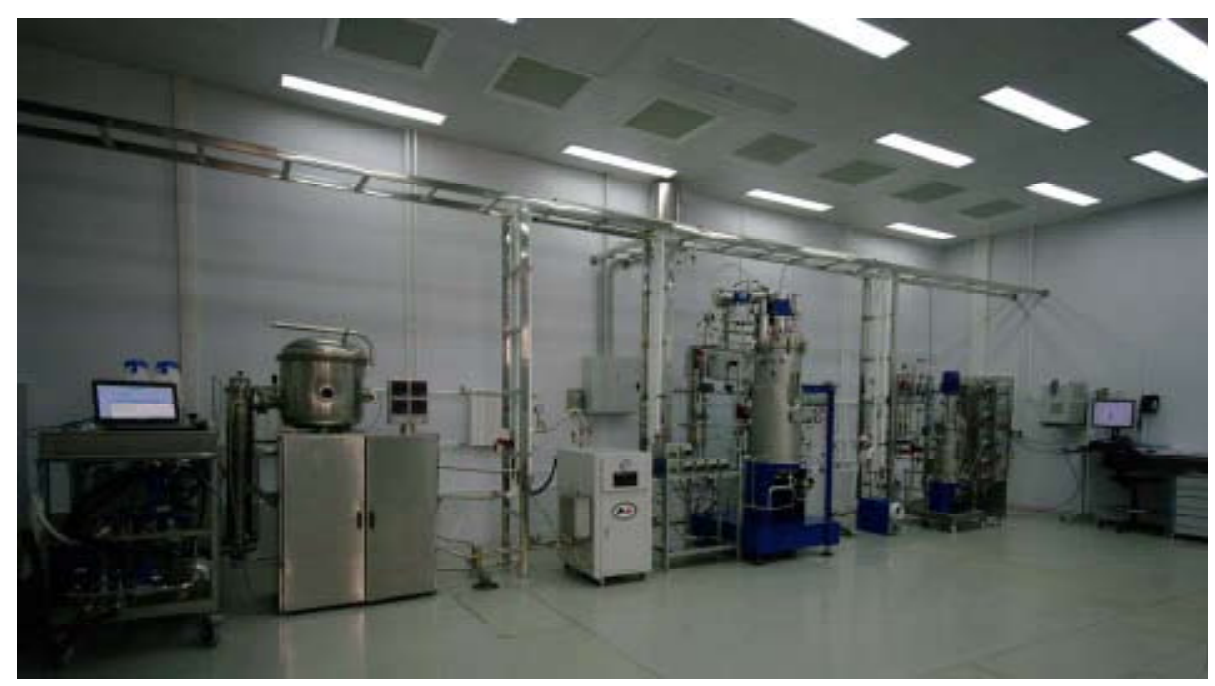

Рис. 5. Фото ферментационной линии «Bioengineering» (Швейцария) опытного производства полимеров

Таблица 2. Основное технологическое оборудование опытного производства полимеров

\begin{tabular}{|c|c|c|}
\hline Позиция* & Наименование и основные характеристики & $\begin{array}{l}\text { Количество } \\
\text { (штук) }\end{array}$ \\
\hline 1 & Компрессор. REMEZA СБ4/Ф-500.OL150II. Ресивер, 500 л & 1 \\
\hline 2 & $\begin{array}{l}\text { Парогенератор. Biotron Pyeng HWA } \\
\text { Производительность по пару, } 50 \text { кг/ч }\end{array}$ & 1 \\
\hline 3 & Автоклав вертикальный Sanyo MLS-3780 V=75 л & 2 \\
\hline 4 & $\begin{array}{l}\text { Шейкер-инкубатор. Incubator Shaker Innova® серии } 44 \text { New Brunswick Для } \\
\text { колб объемом от } 1,0 \text { до 5,0 л. }\end{array}$ & 2 \\
\hline 5 & $\begin{array}{l}\text { Ферментёр-иннокулятор Bioengineering NLF 22. Сосуд общий объемом } 30 \text { л, } \\
\text { рабочий объем от } 5 \text { до } 20 \text { л }\end{array}$ & 1 \\
\hline 6 & $\begin{array}{l}\text { Насос перистальтический Ismatec Flowmaster FMT300 } \\
\text { Производительность от } 37 \text { мл/мин до } 13 \text { л/мин }\end{array}$ & 5 \\
\hline 7 & Ёмкость, V=130 л & 1 \\
\hline 8 & Центрифуга Avanti & 1 \\
\hline 9 & Ёмкость, V=100 л & 1 \\
\hline 10 & $\begin{array}{l}\text { Производственный ферментёр Bioengineering тип Р-сосуд общий объем } 150 \\
\text { л, рабочий объем от } 25 \text { до100 л }\end{array}$ & 1 \\
\hline 11 & Сборник культуральной жидкости. V=130 л & 1 \\
\hline 12 & $\begin{array}{l}\text { Вакуум-выпарная установка «УВВ-50» } \\
\text { Производительность по выпариваемой влаге, 20-50 кг/ч }\end{array}$ & 1 \\
\hline 13 & Сборник чистого раствора $\mathrm{V}=50$ л & 1 \\
\hline 14 & Сборник отработанного растворителя & 1 \\
\hline 15 & Экстрактор с мешалкой, 50 л & 1 \\
\hline 16 & Ёмкость с мешалкой V=50 л & 1 \\
\hline 17 & Центрифуга Avanti J-HC & 1 \\
\hline 20 & Аквадистиллятор электрический. АЭ-25 МО. Производительность 25 л/ч & 1 \\
\hline
\end{tabular}

* Позиция оборудования в таблице соответствует номеру оборудования на технологической схеме (см. рис. 6). 


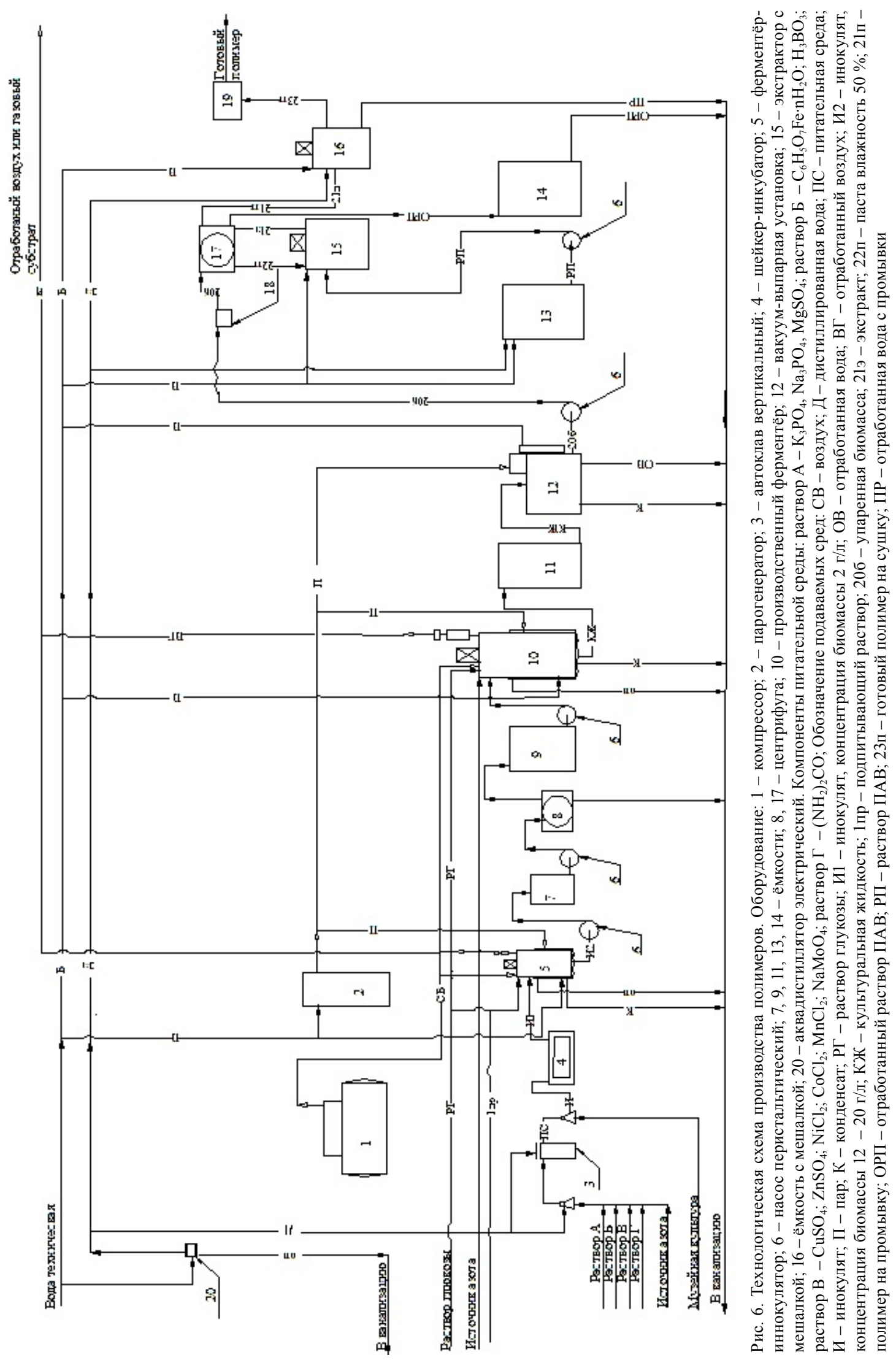


- центрифугирование сгущенной культуры и получение пасты биомассы;

- выделение и очистка полимера;

- сушка, анализ и затаривание продукта (ПГА).

На предферментационной стадии осуществляется подготовка и стерилизация оборудования водяным паром в течение 60 мин при давлении 0,12 МПа. Для получения пара используется электрический парогенератор (2) производительностью 50 кг/ч. Стеклянные колбы, а также маточные растворы стерилизуются в автоклаве (3). Для приготовления среды используют пять растворов: А, Б, $\mathrm{B}, \Gamma$, Д (раствор $\mathrm{A}-\mathrm{K}_{3} \mathrm{PO}_{4}, \mathrm{Na}_{3} \mathrm{PO}_{4}, \mathrm{MgSO}_{4}$; раствор Б - $\mathrm{C}_{6} \mathrm{H}_{5} \mathrm{O}_{7} \mathrm{Fe} \cdot \mathrm{nH}_{2} \mathrm{O} ; \mathrm{H}_{3} \mathrm{BO}_{3}$; pacтвор В - $\mathrm{CuSO}_{4} ; \mathrm{ZnSO}_{4} ; \mathrm{NiCl}_{2} ; \mathrm{CoCl}_{2} ; \mathrm{MnCl}_{2}$; $\mathrm{NaMoO}_{4}$; раствор $\Gamma-\left(\mathrm{NH}_{2}\right)_{2} \mathrm{CO}$; раствор Д $\mathrm{C}_{6} \mathrm{H}_{12} \mathrm{O}_{6}$ или синтез-газ).

После стерилизации в колбах (ёмкость 2 л) готовят среду и вносят культуpy C. eutrophus B-10646. После чего колбы устанавливают в шейкер-инкубатор (4) и инкубируют в течение $20-22$ ч при $30{ }^{\circ} \mathrm{C}$. Затем полученный инокулят переносят в ферментёр-инокулятор (5), в котором уже находится приготовленная среда в количестве 10 л. Процесс выращивания биомассы в ферментёре-инокуляторе длится 4-6 ч в режиме хемостата. Это позволяет получить необходимое для засева производственного аппарата количество инокулята, который концентрируют на центрифуге (8). Полученный инокулят в количестве 100 л по стерильной посевной линии поступает в производственный ферментёр (10). Культивирование осуществляется в две стадии. На первой стадии происходит накопление биомассы в течение 24 ч до концентрации 40-50 г/л. На данном этапе используются подпитывающие растворы солей азота и глюкозы. На второй стадии лимитируют по- дачу азота (подпитывающий раствор карбамида). В этот момент концентрация клеток перестаёт увеличиваться, а содержание полимера в клетках растёт. Длительность стадии составляет 30 ч.

После процесса ферментации полученная культуральная жидкость сливается в сборник (11), откуда далее поступает в вакуум-выпарную установку (12), где концентрируется до 300 - 350 г/л, а затем перистальтическим насосом (6) подается в сборник упаренной суспензии (18). Упаренную суспензию подвергают дальнейшему концентрированию в центрифуге (17). Полученная паста с влажностью 50 \% подаётся в экстрактор (15); туда же из сборника чистого растворителя (13) подаётся 5\%-ный раствор додецилсульфата натрия в количестве 4-5 л/кг пасты. Экстракцию проводят при температуре $60{ }^{\circ} \mathrm{C}$ в течение часа с постоянным перемешиванием.

Далее полимер отделяют от экстракта в центрифуге (17), полученный фугат направляют на очистку, а полимер подаётся в сборник (16), оснащенный мешалкой, где промывается дистиллированной водой. От промывной жидкости готовый полимер отделяется в центрифуге (17), затем сушится и стерильно упаковывается. Для получения высокоочищенного полимера производят его доочистку при растворении в дихлорметане с последующим осаждением гексаном. Технико-технологические показатели процесса в условиях опытного производства представлены в табл. 3.

Таким образом, осуществлено масштабирование процесса синтеза полимеров в условиях опытного производства и обеспечено получение опытных партий продукта в количествах, необходимых для разработки полимерных изделий и проведения необходимых комплексных испытаний. 
Таблица 3. Технологические показатели опытного производства полимеров

\begin{tabular}{|l|c|}
\hline \multicolumn{1}{|c|}{ Показатель } & 3начение \\
\hline Рабочий объем культуры, л & 100,0 \\
Средняя удельная скорость роста ,ч-1 & 0,1 \\
Конечная концентрация биомассы, г/л & $110 \pm 10$ \\
Конечная концентрация полимера ,\% & $85 \pm 5$ \\
Общий выход биомассы за цикл, кг & $10 \pm 1$ \\
Общий выход полимера за цикл, кг & $9 \pm 1$ \\
Производительность блока концентрирования: & 50,0 \\
$\quad$ выпарной установки, л/ч & 5,0 \\
$\quad$ центрифуги, л/ч & не более 5,0 \\
потери биомассы при концентрировании, \% & не мее 85,0 \\
Полнота экстракции полимера, \% & не более 15,0 \\
Потери при экстракции, \% & 1,70 \\
Продуктивность процесса по биомассе (АСБ), кг/л ч & 1,45 \\
Продуктивность процесса по продукту, кг/л ч & \\
\hline
\end{tabular}

Таблица 4. Удельные затраты реагентов на синтез 1 кг ПГА (гомополимер-3-гидроксимасляной кислоты П(ЗГБ)

\begin{tabular}{|c|c|}
\hline Показатель & $\begin{array}{c}\text { Значение } \\
\text { параметра }\end{array}$ \\
\hline $\begin{array}{l}\text { Расход воздуха, } \text { м }^{3} / \kappa г \\
\text { Глюкоза , кг/кг }\end{array}$ & $\begin{array}{c}20,0 \\
2,9 \pm 0,1\end{array}$ \\
\hline $\begin{array}{l}\text { Расход солей, кг/кг: } \\
-\quad \text { мочевина } \\
-\quad \text { фосфаты калия и натрия водные (безводные) } \\
-\quad \text { магний сернокислый } \\
-\quad \text { железо лимоннокислое } \\
-\quad \text { микроэлементы } \\
\end{array}$ & $\begin{array}{c}0,11 \pm 0,1 \\
0,17 \pm 0,1 \\
0,01 \pm 0,01 \\
0,003 \pm 0,001 \\
0,001 \pm 0,001\end{array}$ \\
\hline $\begin{array}{l}\text { Расход воды: } \\
\text { Вода для приготовления сред, кг/кг } \\
\text { Технологическая вода, } \text { м }^{3} \text { кг }\end{array}$ & $\begin{array}{c}50,0 \pm 5 \\
3,0 \pm 1\end{array}$ \\
\hline $\begin{array}{l}\text { Экстракция } \\
\text { Расход ДДС-Na кг/кг } \\
\text { Вода, } \text { м }^{3} \text { кг }\end{array}$ & $\begin{array}{c}0,6 \pm 0,1 \\
50 \pm 5\end{array}$ \\
\hline
\end{tabular}

\section{Материальные затраты на синтез ПГА}

Реализация устойчивого и регламентированного процесса синтеза полимеров бактериями C. eutrophus B-10646 в масштабированном варианте позволила определить материальные затраты, включая затраты углеродного субстрата, воды, минеральных солей и реагентов на выделение полимера (табл. 4).

\section{Заключение}

В результате комплексных исследований с использованием полученного штамма C. eutrophus В10646 и выполненной оптимизации процесса биосинтеза ПГА достигнуты показатели, положенные в основу разработки проекта опытного производства. В соответствии с разработанным проектом укомплектовано и введено в строй опытное производство, включающее ферментацион- 
ную линию «Bioengineering» (Швейцария) и блоки получения инокулята и питательных сред, выделения и очитки полимеров. Опытное производство введено в строй. Достигнутые показатели процесса биосинтеза ПГА при конечной концентрации биомассы клеток и полимера в культуре C. eutrophus В10646 (110 \pm 10$)$ г/л и $(85 \pm 5) \%$ составили по биомассе и ПГА 1,7 и 1,4 г/л·ч соответствен- но, что вдвое превосходит ранее достигнутые показатели в культуре R. eutrophus $\mathrm{B} 5786$ на фруктозе. Масштабирование технологии обеспечило получение опытных партий полимеров в количествах, необходимых для проведения комплекса регламентированных исследований, разработки и стандартизации специализированной полимерной продукции.

Работа выполнена при поддержке гранта Российского научного фонда № 14-26-00039.

\section{Список литературы}

1. Волова Т.Г., Войнов Н.А., Муратов В.С., Бубнов Н.В., Гурулев К.В., Калачева Г.С., Горбунова Н.В., Плотников В.Ф., Жила Н.О., Шишацкая Е.И., Беляева О.Г. (2006). Опытное производство разрушаемых биополимеров. Биотехнология 6: 28-34.

2. Volova T.G., Kiselev E.G., Shishatskaya E.I., Zhila N.O., Boyandin A.N., Syrvacheva D., Vinogradova O.N., Kalacheva G.N., Vasiliev A., Peterson I. (2013) Cell growth and PHA accumulation from $\mathrm{CO}_{2}$ and $\mathrm{H}_{2}$ of a hydrogen-oxidizing bacterium, Cupriavidus eutrophus B-10646. Bioresource Technology 146: 215-222.

3. Volova T.G., Kiselev E.G., Vinogradova O.N., Nikolaeva E.D., Chistyakov A.A., Sukovatyi A.G., Shishatskaya E.I. (2014). A glucose-utilizing strain, Cupriavidus eutrophus B-10646: growth kinetics, characterization and synthesis of multicomponent PHAs. PloS One 9: e87551.

4. ГОСТ Р 52249-2009 Правила производства и контроля качества лекарственных средств. 